\title{
STRATEGI GERAKAN PENERAPAN SYARIAT ISLAM FRONT PEMBELA ISLAM DI MOJOKERTO
}

\author{
M. Mujibuddin \\ UIN Sunan Kalijaga Yogyakarta \\ Email: mujibuddin79@gmail.com
}

\begin{abstract}
Abstrak
Penelitian ini bertujuan untuk menganalisi gerakan penerapan syariat Islam oleh Front Pembela Islam (FPI) di Mojokerto. Mojokerto adalah kota yang memiliki akar tradisi NU yang kuat. Selama ini, NU Mojokerto tidak pernah melakukan aksi kekerasan atas nama agama. Akan tetapi kuatnya tradisi NU di Mojokerto bukan menjadi jaminan untuk menahan laju isu radikal. Penelitian ini mencoba menganalisis strategi penjaringan massa sekaligus upayanya dalam menerapkan syariat Islam di Mojokerto. Penelitian ini merupakan studi lapangan. Penelitian ini menggunakan teori kesempatan politik (political opportunity) untuk menganalisis gerakannya. Penelitian ini menemukan bahwa terdapat dua strategi yang dilakukan oleh FPI untuk menerapkan syariat Islam di Mojokerto. Pertama, FPI memanfaatkan demokrasi untuk mendukung calon pemimpin yang disinyalir satu misi dengannnya. FPI mendorong anggotanya untuk mengajak masyarakat sekitar memilih pemimpin yang mendukung syariat Islam. Kedua, FPI bergerak sendiri dengan cara sweeping apabila ditemukan tempat maksiat. Kesempatan politik yang terbuka sejak reformasi memudahkan FPI untuk memobilisasi massa, sehingga FPI bebas bergerak dan berpendapat menyuarakan aspirasinya dalam bentuk apapun.
\end{abstract}

Kata Kunci:

FPI Mojokerto, Radikalisme, Hukum Islam, Politik Islam, Kesempatan Politik

\begin{abstract}
This study aims to analyze the movement for the application of Islamic law by the Islamic Defenders Front (FPI) in Mojokerto. Mojokerto is a city with strong NU tradition roots as NU Mojokerto is one of the largest Islamic organizations in this city. So far, NU Mojokerto has never carried out acts of violence in the name of religion. However, the strong tradition of $N U$ does not guarantee the development of radical issues in Mojokerto. This study tries to analyze the strategy of mass networking as well as its efforts in implementing Islamic law in Mojokerto. This research is a field study that uses political opportunity theory to analyze the movement. Based on the research, the author found that there were two strategies undertaken by FPI to implement Islamic law in Mojokerto. First, FPI uses democracy to support candidate leaders who are on the same mission as them. In addition, FPI also encourages society to choose a leader who supports the implementation of Islamic law. Secondly, FPI takes an action in doing the raid in particular places around the city. The political opportunities that have opened since the reformation era have made it easier for FPI to mobilize the masses, FPI has the freedom to express its opinion in various actions.
\end{abstract}




\section{Keywords: \\ FPI Mojokerto, Radicalism, Islamic Law, Islamic Politic, Political Chance}

\section{Pendahuluan}

Penelitian ini bertujuan untuk menganalisis tentang gerakan penerapan syariat Islam Front Pembela Islam (FPI) di Mojokerto. Gerakan penerapan syariat Islam di Mojokerto merupakan fenomena baru yang lahir di era pasca-reformasi. Selama ini, wacana Islam di Mojokerto tidak cenderung ke ranah politik, melainkan ke kultural. Hal ini bisa dipahami berdasarkan fakta historis bahwa konstruksi sosial-kultural masyarakat Mojokerto dibentuk oleh Nahdlatul Ulama. Dari segi politik, kedua ormas ini memiliki perbedaan yang tajam. NU lebih bergerak ke ranah kultural sedangkan FPI ke ranah politik. Penelitian ini akan mengungkapkan strategi FPI untuk menerapkan sistem syariat di Mojokerto baik melalui pendekatan struktural maupun kultural.

Gerakan penerapan syariat Islam di Indonesia bukan fenomena baru lagi. Ketika Indonesia memasuki babak baru di era desentralisasi, daerah-daerah di Indonesia diberi kebebasan untuk mengatur daerah sendiri. Penelitian yang dilakukan oleh Michael Buehler menunjukkan bahwa kaum muslim memiliki pengaruh besar dalam demokratisasi di Indonesia, terutama pasca reformasi. Keadaan ini didukung dengan adanya gerakan dari kelompok Islam untuk menerapkan sistem syariat di daerah ${ }^{1}$. Penelitian Zaki Mubarak dan Iim Halimatusa'diyah menjadi bukti dari argumentasi Buehler bahwa di sebagian daerah Jawa Barat telah menerapkan syariat Islam. Zaki Mubarak juga menjelaskan tentang bagaimana proses awal terbentuknya peraturan daerah (Perda) syariat Islam yang diinisiasi oleh sebagian kelompok muslim. ${ }^{2}$

Berbeda dengan penelitian sebelumnya, penelitian ini memfokuskan pada gerakan FPI dalam mengupayakan penerapan syariat Islam di Mojokerto. Secara kultural, Mojokerto merupakan kota/kabupaten yang memiliki kultur keagamaan keNU-an. Gerakan NU selama ini difokuskan pada ranah kultural ketimbang politik. Oleh karena itu, menarik untuk melihat bagaimana gerakan penerapan syariat yang dilakukan oleh FPI di tengah kultur masyarakat berciri ke-NU-an.

\footnotetext{
${ }^{1}$ Michael Buehler, The Politics of Shari'a Law: Islamist Activists and the State in Democratizing Indonesia (Cambridge University Press, 2016).

${ }^{2}$ M. Zaki Mubarak \& Iim Halimatusa'diyah, Politik Syariat Islam Idiologi Dan Pragmatisme (Jakarta: Pustaka LP3ES, 2014).
} 
Kehadiran FPI memberi warna baru dalam keormasan Islam di Mojokerto. FPI bisa beradaptasi dengan masyarakat Mojokerto dengan mudah. Hal ini sebabkan oleh beberapa hal; Pertama, secara madzab antara NU dan FPI sama-sama menggunakan madzhab Syafi'i; Kedua, anggota FPI Mojokerto memang asli warga sekitar. Dua kondisi seperti ini yang mempermudah untuk merekrut anggota.

Selain itu, upaya penerapan syariat di Mojokerto merupakan gerakan model baru FPI di daerah-daerah. Selama ini FPI dikenal sebagai organisasi yang tidak taat aturan. Aksi kekerasan pun menjadi wajah mereka sampai-sampai dijuluki sebagai preman berjubah putih. Namun, sejak tahun 2013, tepatnya setelah Milad FPI di Bogor, FPI Pusat menginstruksikan kepada para anggotanya di daerah-daerah untuk memperjuangkan penerapan syariat Islam dalam ranah politik.

\section{Kajian Teoretis}

Untuk menganalisis data-data yang diperoleh, maka penelitian ini akan meminjam beberapa konsep sebagai pisau analisis, yakni teori gerakan sosial baru terutama yang berkaitan dengan kesempatan politik (political opportunities), struktur mobilisasi dan sumber daya, serta framing proses. Ketiga pandangan tersebut bisa saling melengkapi satu sama lain. ${ }^{3}$

Menurut Doug Mc Adam dan Sidney Tarrow terdapat beberapa karakteristik untuk mengidentifikasi teori kesempatan politik. Pertama, keterbukaan sistem politik dan akses ke lembaga politik semakin mudah, sehingga gerakan sosial mudah berkembang. Kedua, negara sedang mengalami ketidakseimbangan politik sehingga membentuk keseimbangan baru. Ketiga, adanya konflik di dalam elit politik yang dimanfaatkan oleh aktor gerakan sosial untuk melakukan perubahan. Keempat, aktor gerakan sosial bekerjasama dengan para elit politik. ${ }^{4}$

Sementara terkait dengan teori struktur mobilisasi dan sumber daya menekankapn pada aspek rasionalitas para aktor gerakan sosial. Klandermans menyatakan bahwa Resource Mobilization Theory (RMT) menekankan pada pentingnya faktor-faktor struktural (structural factors), seperti ketersediaan sumberdaya (the

\footnotetext{
${ }^{3}$ Doug McAdam et al., Comparative Perspectives on Social Movements: Political Opportunities, Mobilizing Structures, and Cultural Framings (Cambridge University Press, 1996).

${ }^{4}$ Abdul Wahib Situmorang, Gerakan Sosial: Teori Dan Praktik (Yogyakarta: Pustaka Pelajar, 2013), h. 34.
} 
availibilty of resources) untuk kolektivitas dan posisi individu dalam jaringan sosial, serta menekankan rasionalitas tentang partisipasi dalam suatu gerakan sosial. ${ }^{5}$ Partisipasi dalam gerakan sosial dipandang bukan sebagai konsekuensi dari sifat-sifat predisposisi psikologis, tetapi sebagai hasil proses-proses keputusan rasional di mana orang melakukan pertimbangan untung dan rugi (reward and cost) atas keterlibatannya dalam suatu gerakan sosial.

Teori yang tidak kalah pentingnya untuk menganalisis gerakan berbasis keagamaan adalah proses pembingkaian isu (framing process). Teoritis gerakan sosial menggagas suatu konsep skema mengenai meaning construction dengan menggunakan term yang disebut framing. ${ }^{6}$ Konsep frame mengambil dari Erving Goffman yang mengartikan bahwa frame merupakan skema pembacaan, interpretasi, pemetaan, identifikasi serta memberikan label terhadap kejadian-kejadian yang muncul di kehidupan sosial. Benford dan Snow menambahkan bahwa ada tiga step dalam proses ini yaitu diagnosis, penandaan dan motivational. ${ }^{7}$ Dalam hal ini, frame digunakan untuk mendiagnosis atau mengidentifikasi suatu kejadian tertentu untuk dijadikan sebagai landasan mobilisasi massa.

Teori kesempatan politik digunakan untuk menjelaskan awal kemunculan FPI di Mojokerto yang muncul karena keterbukaan sistem dan akses politik. Kemudian teori framing digunakan untuk pembingkaian isu tertentu yang berkaitan dengan syariat Islam sebagai basis rasionalisasi gerakan sosial. Dengan begitu, mobilisasi massa dapat dilakukan.

\section{Metode Penelitian}

Penelitian ini menggunakan metode kualitatif. Penggunaan metode ini untuk mengkaji secara mendalam terkait dengan upaya syariatisasi FPI di Mojokerto. Oleh karena itu, metode pencarian data yang digunakan dalam penelitian ini adalah wawancara, observasi dan dokumentasi. Wawancara dilakukan dengan ketua dan

\footnotetext{
${ }^{5}$ Bert Klandermans, "Mobilization and Participation: Social-Psychological Expansions of Resource Mobilization Theory" dalam American Sociological Review, Vol. 49, No. 5 (1984), h. 583-600.

${ }^{6}$ Benford \& David Snow, "Framing Processes and Social Movements: An Overview and Assessment” dalam Journal Annu. Rev. Social, Vol. 26 (2000), h. 611-39.

${ }^{7}$ Mario Diani \& Donatella Della Porta, Social Movemente: An Introduction (New York: Blackwell Publishing Ltd, 2006), h. 74.
} 
anggota FPI Mojokerto. Sementara observasi digunakan untuk melihat gerakan secara umum FPI di Mojokerto.

\section{Perkembangan Front Pembela Islam Mojokerto}

FPI Mojokerto lahir pada tahun 2000-an yang diawali dengan pengajian Tajul Muslimin di rumah Abah Fanani. Menurut penuturan Yus Aliansyah, pada tahun 2000an, dua tahun setelah FPI terbentuk, ${ }^{8}$ Habib Rizieq sering mengunjungi pengajian Tajum Muslimin. Habib Rizieq menawarkan kepada Kyai Sa'dullah, selaku pengisi pengajian tersebut, untuk mendirikan FPI cabang wilayah Jawa Timur dan Mojokerto. Pada saat itu FPI Mojokerto terbentuk dan anggota pengajian Tajul Muslimin menjadi partisipannya.

Secara kultural para anggota FPI Mojokerto masih mengikuti tradisi NU. Namun secara sikap politik mereka lebih bersepakat dengan FPI karena dianggap lebih tegas ketimbang NU. Hal ini terbuktik ketika melihat geneologi anggota FPI Mojokerto yang notabene dibesarkan dalam tradisi NU. Yus Aliansyah sendiri pada mulanya merupakan salah satu tokoh petinggi NU di wilayah kecamatan Sooko Mojokerto. Namun karena ia tertarik dengan sikap FPI dalam persoalan gerakan dan politik, ia kemudian beralih dari NU ke FPI.

Berawal dari kegiatan pengajian seperti itu, FPI Mojokerto semakin berkembang. Di samping itu, pola rekrutmen terhadap pemuda-pemuda di sekitar Sooko turut andil dalam menambah jumlah anggota FPI. Terdapat dua pola untuk mendapatkan jumlah pengikut semakin besar. Pertama, adanya bentuk kecintaan terhadap habaib. Perlu diketahui bahwa dalam struktur FPI terdapat beberapa bagian dan bagian paling atas diisi oleh para habaib. ${ }^{9}$ Secara sederhana, gerakan FPI di bagi menjadi dua bagian yaitu jamaah FPI dan laskar FPI. Jamaah FPI bertujuan untuk kegiatan keagamaan seperti pengajian, bakti sosial, dan pendidikan. Sementara laskar FPI ditugaskan untuk memberantas berbagai kemaksiatan di masyarakat. Keberadaan laskah FPI ini apa yang disebut oleh Ian Wilson sebagai “centang polisi”. ${ }^{10}$ Ia bertindak

\footnotetext{
${ }^{8}$ Yus Aliansyah, Petinggi FPI Mojokerto, wawancara, 18 Mei 2017.

${ }^{9} \mathrm{Al}-Z a s t r o u w ~ N g$, Gerakan Islam Simbolik; Politik Kepentingan FPI (Yogyakarta: LKIS, 2006), h. 94.

${ }^{10}$ Ian D. Wilson, Politik Jatah Preman: Ormas dan Kuasa Jalanan di Indonesia Pasca-Orde Baru Jakarta: Marjin Kiri, 2018), h. 15-20.
} 
seolah-olah sebagai polisi dadakan. Aturan yang dipegang tidak berdasarkan prosedur yang ada melainkan disesuaikan dengan kaidah gerakan FPI.

Pola rekrutmen semacam ini terlihat di kalangan muda FPI Mojokerto. Berdasarkan kecintaannya terhadap habaib, mereka ikut serta dalam aksi dan wacana yang dibangun oleh sang Habib. Hal ini terlihat pada saat peneliti mengobservasi tempat berkumpulnya (basecamp) FPI Sooko. Di sana terdapat beberapa anak muda yang usianya berkisar antara 20-35 tahun. Di antaranya ada yang mengatakan bahwa salah satu motif dibalik keikutsertaannya dalam FPI adalah karena mereka cinta dengan habaib, terutama Habib Rizieq. ${ }^{11}$

Posisi Habib dalam struktur FPI sangatlah penting. Sebab mereka dianggap orang yang telah mendapat legitimasi secara agama maupun status sosial. Terkait dengan keikutsertaan para pemuda Mojokerto dalam FPI, terdapat analisis yang menarik dari Wongkaren yang menganalisis tentang keikutsertaan pemuda dalam gerakan radikal. Ia menjelaskan bahwa:

“.... Tidak sedikit di antara pelaku aksi kekerasan berbasis fanatisme berlebihan terhadap keyakinan/agama mengakibatkan nilai luhur yang dijunjung ajaran agamanya sendiri... Kekurangpahaman kebanyakan pelaku aksi tentang hakikat spiritualitas dalam ajaran agamanya terbentuk secara garis besar melalui dua kondisi. Pertama, si pelaku yang berlatar belakang sekolah agama terkondisi sejak kecil untuk belajar agama dengan konten yang tidak terlalu berfokus pada nilai luhur yang dijunjung ajaran agama tersebut, melainkan lebih menekankan pada penegakkan aturan dan pelaksanaan kegiatan ritual..... Kedua, si pelaku yang tidak berlatar belakang sekolah agama justru baru saja belajar agama sehingga mengalami fase euforia.... pelaku di wilayah kondisi kedua ini menanggalkan daya pikir kritisnya dan menyerap secara bulat-bulat ajaran sang guru yang menjadi inspirator utama yang mengubah hidupnya. Ia kemudian ingin melakukan revolusi, yaitu perjalanan drastis dari 'no body' (bukan siapasiapa) menjadi 'somebody' (seseorang yang berarti), sehingga tak heran mengubah secara dramatis perilakunya sehari-hari."12

Kedua, pola rekrutmen yang dilakukan oleh Yus Aliansyah adalah dengan mengajak anak-anak muda yang sedang minum-minuman beralkohol di sekitar Lapangan Brangkal Sooko. Kebetulan lapangan tersebut berdekatan dengan rumah Yus Aliansyah. Oleh karena itu, apabila mereka ditemukan sedang bermabuk-mabukan,

${ }^{11}$ Unung, Anggota FPI Mojokerto, wawancara, 20 Mei 2017.

${ }^{12 Z}$ ora A. Wongkaren, "Agama dan Fanatisme Berlebihan" dalam https://gagasanhukum.word press.com/tag/zora-a-wongkaren/ diakses 10 Mei 2020. 
maka mereka diajak untuk terlibat dalam aksi FPI. Sebagaimana yang telah diungkapkan oleh Yus Aliansyah yang mengatakan bahwa:

Biyen iku mas, nang lapangan kunu akeh arek mendem ben bengi. Polisi gak wani marani. La pas FPI kate demo arek-arek iku tak jak dan gelem yoan melok. Sak marine iku arek-arek mesti takon, mas Yus gak nok demo-demo mane a?. (Dulu itu mas, di lapangan sana tiap malam banyak anak mabuk. Polisi tidak berani menghampiri. Kalau FPI mau demo anak-anak itu saya ajak dan ternyata mau ikut. Setelah itu mereka sering tanya, mas Yus nggak ada demo-demo lagi?).

Alasan Yus Aliansyah ketika mengajak mereka untuk ikut dalam aksi adalah untuk menghindarkan dari kebiasaan minum-minum. Bagi Yus Aliansyah mengajak mereka untuk ikut demo dan aksi yang lain lebih positif dibandingkan dengan kebiasaan mereka selama ini. Anggota seperti ini yang dimanfaatkan oleh FPI untuk mengisi struktur Laskar Jihad sebagai basis untuk aksi sweeping. Meskipun struktur FPI Mojokerto hingga tahun 2017 belum ada pembagian yang pasti antara bidang keagamaan dan Laskar Jihad, akan tetapi secara berangsur-angsur, dengan melihat pola rekrutmen dan aksi yang dilakukan, mereka bisa mengembangkan FPI lebih besar dan berkembang.

Secara kuantitas, keanggotaan FPI di Mojokerto belum ada data secara pasti. Namun yang jelas dari pernyataan Yus Aliansyah mengatakan bahwa simpatisan FPI sudah menyebar hampir di semua kecamatan Mojokerto dan wilayah kota Mojokerto. ${ }^{13}$ Peningkatan ini bisa terjadi mengingat secara teologi keagamaan antara FPI dan NU, sebagaimana yang dianut oleh mayoritas Islam di Mojokerto, memiliki persamaan. Habib Rizieq mengatakan bahwa paham teologi yang dianut FPI adalah Ahlusunnah wal Jamaah dengan mengikuti madzhab fiqih, seperti halnya yang dianut oleh NU. Persamaan teologi Syafi'i mempermudah seseorang untuk masuk dalam organisasi FPI.

Keberadaan FPI di Mojokerto tidak ada perbedaan yang signifikan dalam hal teologi. Anggota FPI masih melakukan tradisi-tradisi NU pada umumnya, seperti tahlilan, barzanji, sholawatan, dan tradisi lainnya. Maka dari itu, adanya peningkatan jumlah pengikut FPI, baik yang menjadi anggota maupun partisipan, disebabkan oleh adanya persamaan teologi fiqih sunni dengan NU.

${ }^{13}$ Yus Aliansyah, Petinggi FPI Mojokerto, wawancara, 18 Mei 2017. 
Anggota dan partisipan FPI di Mojokerto yang berasal dari kalangan NU bisa diidentifikasi melalui sikap politiknya. Ketika pemilu datang, poros politiknya akan terlihat. Hal ini disebabkan karena sikap politik NU dan FPI berbeda. FPI cenderung memilih partai Islam dan calon pemimpin yang paham tentang agama, sementara NU bersikap netral terhadap politik meskipun PKB banyak didominasi oleh orang-orang NU.

\section{Strategi Penerapan Syariat Islam di Mojokerto}

Sebagaimana yang sudah diketahui secara umum bahwa FPI memiliki cita-cita politik penerapan syariat Islam. Meskipun FPI bukan partai politik, namun kehadirannya dalam keormasan Islam di Indonesia turut mewarnai perpolitikan nasional. Keterlibatan anggota atau kadernya yang menyebar di Indonesia telah memberikan pengaruh dalam perpolitikan daerah. Apabila hal ini berjalan dengan lancar, maka upaya untuk mendirikan "NKRI Bersyariat” akan terwujud.

Namun sebelum itu, perlu untuk diketahui terlebih dahulu tentang pemikiran politik Habib Rizieq untuk memudahkan memahami gerakan FPI di Mojokerto. Habib Rizieq memandang bahwa Pemerintahan Islam adalah pemerintahan yang berdiri di atas syariat Islam. Pemikiran politik dari luar Islam dilarang untuk diterapkan. Pemikiran atau nalar politik Habib Rizieq dipengaruhi oleh Sayyid Qutb yang mengkritik segala sistem produk manusia, termasuk juga politik. Sayyid Qutb berpandangan bahwa apabila masyarakat tidak menjalankan sistem syariat Islam maka ia termasuk ke dalam jahiliyah. ${ }^{14}$ Sementara pemerintahan yang berasaskan Islam disebut dengan hakimiyat. ${ }^{15}$

Habib Rizieq menolak hukum Indonesia saat ini dikarenakan masih didominasi oleh sistem Barat. Negara Islam dalam nalar politik Habib Rizieq adalah sebuah negara yang menerapkan hukum Islam, karena menurutnya hukum Islam adalah hukum Tuhan yang tidak memiliki kecacatan sedikitpun. Sementara hukum Indonesia saat ini bagi Habib Rizieq masih memiliki kecacatan. ${ }^{16}$ Apabila umat Islam di Indonesia masih menerapkan sistem demokrasi, maka ia masuk dalam kategori jahiliyah. Oleh karena

\footnotetext{
${ }^{14}$ Sayyid Qutb, Petunjuk Jalan (Jakarta: Media Dakwah, 1994).

${ }^{15}$ Sayed Khatab, "Hakimiyyah and Jahiliyyah in the Thought of Sayyid Qutb" dalam Middle Eastern Studies, Vol. 38, No. 3 (2002), h. 145-70.

${ }^{16} \mathrm{Al}-\mathrm{Habib}$ Muhammad Rizieq bin Husein Syihab, "Pengaruh Pancasila Terhadap Penerapan Syariat Islam di Indonesia". Disertasi. (Kuala Lumpur: Jabatan Fiqh dan Usul, Akademi Pengajian Islam, Universiti Malaya, 2012), h. 257-63.
} 
itu, Habib Rizieq dengan FPI-nya mencoba menghilangkan kejahiliyahan yang dilahirkan dari sistem demokrasi di Indonesia dengan berbagai macam cara, sebagaimana terlihat di FPI Mojokerto.

Atas dasar kejahiliyan Indonesia Habib Rizieq dan FPI mencoba menciptakan tatanan masyarakat yang Islami yaitu dengan menegakkan hukum Tuhan (hakimiyat). Tidak ada yang lebih berkuasa dari pada Tuhan. Masyarakat di negara demokrasi yang lebih mempercayai suara rakyat dianggap telah keluar dari hukum Tuhan. Maka dari itu Habib Rizieq menawarkan untuk menegakkan NKRI Bersyariat sebagai model bernegara di Indonesia. ${ }^{17}$ NKRI Bersyariat di bawah payung Tuhan yang memiliki perbedaan dengan pemikiran politik Islam lainnya di Indonesia. Melalui pemikiran ini, Habib Rizieq mengorganisir seluruh anggota dan partisan FPI untuk terlibat dalam membentuk atau mendirikan NKRI Bersyariat di daerah masing-masing. Apabila daerah-daerah sudah menerapkan syariat, maka untuk mendirikan NKRI Bersyariat secara nasional tidak akan sulit.

Terdapat dua strategi yang digunakan oleh FPI Mojokerto untuk menerapkan syariat Islam, yakni ikut serta dalam pemilu dan melakukan sweeping tempat-tempat yang dianggap maksiat. ${ }^{18}$ Keikutsertaan FPI Mojokerto dalam pemilu didasarkan atas pertimbangan calon pemimpin. Apabila calon tersebut memahami agama dan bisa diajak kompromi untuk membuat aturan syariat, maka ia akan dipilih. Kasus pemilihan walikota Mojokerto pada tahun 2013 yang dimenangkan oleh Mas'ud Yunus adalah contoh bagaiman FPI beserta kelompok lainnya bergabung untuk mendukungnya. Bagi FPI Mojokerto, sosok Mas'ud Yunus adalah tokoh agama yang paham tentang agama. Di Mojokerto, Mas'ud Yunus dikenal sebagai kiai dan pimpinan pondok pesantren Al Amin Mojokerto. Dengan latar belakang seperti itu, sosok Mas'ud Yunus dirasa ideal untuk dimenangkan dalam pemilu kota Mojokerto periode 2013-2018. ${ }^{19}$

Pemilihan FPI terhadap pemimpin seperti Mas'ud Yunus bukan tanpa alasan. Dalam buku Habib Rizieq yang berjudul "Dialog FPI: Amar Ma'ruf Nahi Munkar"

${ }^{17}$ Ian D. Wilson, "Resisting Democracy: Front Pembela Islam and Indonesia's 2014 Elections" dalam Ulla Fionna (Ed.), ISEAS Perspective: Watching the Indonesian Elections 2014 (Singapore: ISEAS-Yusof Ishak Institute, 2015), h. 32-40.

${ }^{18}$ Yus Aliansyah, Petinggi FPI Mojokerto, wawancara, 18 Mei 2017.

${ }^{19}$ Mas'ud Yunus memenangkan pemilu kota Mojokerto periode 2013-2018. Namun belum sampai selesai masa jabatannya , pada tahun 2017 Mas'ud Yunus ditetapkan tersangka oleh Komisi Pemberantasan Korupsi (KPK) dalam kasus suap pembahasan perubahan APBD Dinas Pekerjasaan Umum dan Penataan Ruang tahun anggaran 2017. 
dijelaskan kriteria-kriteria untuk menjadi seorang pemimpin. Adapun kriteria tersebut antara lain: $\left.{ }^{20} 1\right)$. Beragama Islam dan wajib berjenis kelamin laki-laki dan haram untuk wanita menjadi seorang pemimpin; 2). Beriaman dan bertaqwa kepada Allah SWT; 3). Bersih lahir batin dan tidak cacat; 4). Jujur, aspiratif, dan terbuka; 5). Memiliki visi yang jelas; 6). Siap hidup sederhana; 7). Tidak menjadi budak Amerika dan sekutunya.

Namun ada kekecewaan tersendiri yang dirasakan oleh FPI Mojokerto ketika melihat Mas'ud Yunus sebagai pemimpin ideal untuk Mojokerto. Persoalan tersebut datang dari Mas'ud Yunus sendiri yang mengatakan bahwa beliau akan mengeluarkan masyarakat apabila didapati ikut dalam kelompok FPI. Rafiq beserta teman-teman pemuda FPI sangat menyayangkan pernyataan tersebut. Atas dasar ini kemudian Rafiq dan teman-teman tidak mendukung kepemimpinan Mas'ud Yunus. ${ }^{21}$

Selain persoalan kepemimpinan, persoalan pemilihan partai juga ditentukan. Seperti yang dijelaskan sebelumnya bahwa Habib Rizieq menggolongkan parta-partai di Indonesia menjadi dua, partai setan dan partai Allah. Terkait dengan klasifikasi partai tersebut, Habib Rizieq mencoba mengaplikasikan konsep partai Allah sebagai partai yang memperjuangkan penerapan syariat Islam. Sementara partai setan masuk dalam kategori jahiliyah-nya Sayyid Qutb.

Peran anggota FPI Mojokerto di masyarakat adalah mendorong warga sekitar untuk memilih partai Islam. Yus Aliansyah mengatakan bahwa para pengurus selalu mengingatkan kepada anggotanya ketika menjelang pemilu mereka bergerak untuk mendorong masyarakat agar memilih partai Islam. Apabila skenario ini berhasil, maka untuk mewujudkan Mojokerto sebagai kota yang Islami bisa tercapai. Hal ini disebabkan karena FPI akan memantau dan membuka komunikasi dua arah dengan pemerintahan. FPI mencoba memberikan perspektif syariat Islam dalam perumusan perundangan-undangan daerah.

Penelusuran peneliti menemukan ada dua agenda yang coba didorong ke pemerintah Mojokerto untuk diimplemantasikan yaitu isu prostitusi dan isu minuman keras. Terkait dengan isu prostitusi, di Mojokerto terdapat tempat lokalisasi cukup terkenal di Jawa Timur yang berlokasi di Balong Cangkring (lebih dikenal dengan

\footnotetext{
${ }^{20}$ Habib Muhammad Riziq Shihab, Dialog FPI-Amar Ma'rüf Nabī Munkar (Jakarta: Ibnu Saidah, 2008), h. 6 .

${ }^{21}$ Rafiq, Anggota FPI Mojokerto, wawancara, 17 Mei 2017.
} 
sebutan BC). BC merupakan sebuah kawasan Dolly-nya Mojokerto. Kawasan ini terkenal dengan bisnis prostitusinya. Bahkan ada yang menyebut kawasan ini merupakan tempat terbesar nomor dua di Jawa Timur setelah Dolly Surabaya.

Keberadaan bisnis lokalisasi di BC bermula dari kelompok Wanita Harapan yang dikelola oleh Yayasan Majapahit. Semula yayasan ini berdiri untuk membina tuna susila, tuna wisma dan gelendangan. Namun seiring berjalannya wakut lokasi ini berubah menjadi tempat lokalisasi yang cukup terkenal di Mojokerto. Sebenarnya tempat ini sudah lama hendak ditutup, namun lantaran yayasan ini memiliki badan hukum yang kuat sehingga pemerintah Mojokerto sulit untuk menutupnya. Kesulitan lainnya adalah pemerintah Mojokerto sendiri belum memiliki payung hukum yang kuat untuk menutup lokalisasi tempat tersebut.

Pada tahun 2013, pemerintah Mojokerto mengeluarkan Perda No. 3 tahun 2013 tentang penyelenggaraan ketertiban umum. Dalam pasal 13 disebutkan bahwa pemerintah kota Mojokerto melarang adanya perbuatan prostitusi di kawasan kota. Penertiban kawasan Balong Cangkring hanya dilakukan pada penutupan lokalisasinya bukan pada penutupan yayasan tersebut. ${ }^{22}$ Hal ini sejalan dengan cita-cita Kota Mojokerto yang menegaskan bahwa pada tanggal 29 Mei 2016, Kota Mojokerto harus bebas dari prostitusi. Kegiatan penerbitan tersebut tidak hanya dilakukan di Balong Cangkring saja melainkan juga di warung-warung pinggir jalan By Pass yang melintasi area Kota Mojokerto. ${ }^{23}$

Langkah pemerintah dalam menertibkan kawasan tersebut dengan tiga pendekatan. Pendekatakan pertama dengan penerbitan dan keamanan, pendekatan sosial, dan pendekatan kemanusiaan. Menurut Mas'ud Yunus khusus pendekatakan sosial kemanusiaan, pihaknya berkordinasi dengan Kementerian Sosial dan Biro Kesra Provinsi Jatim yang nantinya setiap Penjajah Seks Komersial (PSK) akan mendapatkan bantua hidup selama tiga bulan sebesar Rp. 300 ribu per bulan, bantuan biaya pemulangan senilai Rp. 250 ribu per orang, bantuan biaya pelatihan Rp. 2 juta per

${ }^{22}$ Peraturan Daerah Kota Mojokerto tentang Penyelenggaraan Ketertiban Umum No. 3, Tahun 2013.

${ }^{23}$ Inilahmojokerto.com, "Mojokerto belum Bebas Prostitusi" dalam https://inilahmojokerto.com /07/12/2016/ mojokerto-belum-bebas-prostitusi/ diakses 08 Mei 2020. 
orang, dan bantuan modal sebesar Rp. 3 juta per orang. ${ }^{24}$ Harapan pemerintah dengan pendekatan tersebut adalah agar penutupan bisa tepat waktu dan terhindar dari bentrokan fisik.

Payung hukum Perda No. 3 tahun 2013 di sisi lain telah memberikan legitimasi bagi FPI untuk memaksa penutupan lokalisasi Balong Cangkring dengan secepatcepatnya. Menurut Yus Aliansyah, sebenarnya wacana penutupan ini sudah diberitahukan kepada pihak yayasan namun mereka tidak menghiraukan. Oleh karena itu, pada tanggal 8 Maret 2016 FPI mendatangi lokalisasi Balong Cangkring meminta untuk menutup paksa prostitusi itu. Menurut Yus Aliansyah, kedatangan FPI pada waktu itu sudah didengar oleh para preman penjaga kawasan Balong Cangkring, oleh karenanya sewaktu FPI datang sudah dihadang oleh para penjaga dan bentrok antar dua belah pihak pun tidak bisa dihindarkan. ${ }^{25}$

Bagi FPI Mojokerto penutupan tempat lokalisasi Balong Cangkring merupakan upaya untuk mewujudkan sebuah kota yang berdasarkan syariat Islam. FPI menganggap bahwa segala bentuk prostitusi dilarang oleh Islam. FPI sudah menunggu momenmomen penting untuk bisa menutup tempat tersebut. Atas dasar Perda di atas, FPI mencoba mengkamuflasekan ideologi gerakannya atas nama membantu pemerintah untuk menertibkan tempat prostitusi. Dari situlah kemudian FPI bisa memobilisasi massa untuk menutupnya.

Cara kedua dalam menerapkan syariat Islam di Mojokerto adalah dengan aksi sweeping. FPI Mojokerto memobilisasi anggotanya untuk ikut serta dalam aksi sweeping. Aksi ini dilakukan untuk menghilangkan hal-hal yang berbau maksiat menurut FPI. Jargon amar ma'ruf nahi munkar merupakan ideologi yang diambil sebagai landasan epistemologi aksi sweepingnya. Habib Rizieq menafsirkan nahi munkar sebagai bentuk perlawanan, baik secara simbolik maupun empirik atas segala bentuk kemungkaran di masyarakat. ${ }^{26}$

FPI membagi kategori munkar ke dalam empat bagian, yaitu 1). Kategori penyakit masyarakat seperti premanisme, minuman keras, perjudian, pelacuran, narkoba

\footnotetext{
${ }^{24}$ Danu Bhirawa, "Kota Mojokerto Targetkan 29 Mei Bebas Prostitusi" dalam https://www. harianbhirawa.co.id/kota-mojokerto-targetkan-29-mei-bebas-prostitusi/ diakses 8 Mei 2020.

${ }^{25}$ Yus Aliansyah, Petinggi FPI Mojokerto, wawancara, 18 Mei 2017. Lihat juga Liputan6.com, "Video: FPI Bentrok dengan Pekerja Lokalisasi Balongcangkring” dalam https://www.liputan6.com/news/read/ 2454450/video-fpi-bentrok-dengan-pekerja-lokalisasi-balongcangkring diakses 10 Mei 2020.

${ }^{26}$ Habib Muhammad Riziq Shihab, (2008), h. 36.
} 
dan sejenisnya. 2). Kategori penyimpangan agama, seperti pelecehan agama, praktik perdukunan, penyimpangan aqidah, pemurtadan, sekularisme, pluralisme, liberalisme, ketakpedulian pada agama dan umat Islam, serta penolakan penerapan syariat. 3). Kategori ketidakadilan dan kedzaliman seperti penculikan aktivis FPI dan fitnah. 4). Kategori sistem non-Islami, seperti nation-state, eknomi sosialis/kapitalis, memilih partai non-Islam, komunisme, dan zionisme. ${ }^{27}$

Keempat kategori di atas digunakan FPI untuk melihat berbagai kemungkaran di Mojokerto. Akan tetapi, Yus Aliansyah menegaskan bahwa selama ini gerakan FPI Mojokerto masih terbatas pada kategori pertama. Hal ini disebabkan karena sumber daya manusia atau anggota FPI di Mojokerto masih sedikit, sehingga area gerakannya juga sempit. Yus Aliansyah menambahkan bahwa aksi sweeping yang dilakukan berdasarkan atas laporan warga atau hasil riset dari anggota FPI sendiri. Tujuan dari sweeping adalah menutup tempat yang dianggap oleh FPI maksiat.

Terdapat aturan atau pedoman yang dipegang oleh FPI sebelum melakukan aksi sweeping untuk menutup tempat yang dianggap maksiat. FPI pertama-tama melihat terlebih dahulu apakah tempat tersebut legal atau illegal. ${ }^{28}$ Apabila tempat tersebut legal maka yang dilakukan adalah: 1). Mengirimkan surat protes dan tuntutan pertama ke lurah dengan tembusan ke pemilik atau penguasa tempat maksiat tersebut. Laporan kepada Binmas, Babinsa, dan ulama kelurahan setempat, serta ke Mabes LPI sebagai laporan pemberitahuan. 2). Bila setelah satu minggu atau satu bulan tidak ditanggapi, maka kirimkan surat protes dan tuntutan kedua ke kantor kecamatan dengan tembusan ke pemilik atau penguasa tempat maksiat tersebut. Kapolsek, Danramil, dan ulama kecamatan setempat, serta Mabes LPI sebagai laporan dan pemberitahuan (dilampirkan surat pertama). 3). Bila setelah satu minggu atau satu bulan tidak ditanggapi, maka kirimkan surat protes dan tuntutan ketiga ke walikota atau bupati, dengan tembusan ke pemilik tempat maksiat tersebut, DPRD, Kapolres, Dandim, dan ulama Kotamadya atau kabupaten setempat, serta Mabes LPI sebagai laporan dan pemberitahuan (dilampirkan surat pertama dan kedua). 4). Bila setelah satu minggu atau satu bulan tidak ditanggapi, maka kirimkan surat protes dan tuntutan terakhir ke gubernur, dengan tembusan ke

${ }^{27}$ Andri Rosadi, Hitam-Putih FPI: Mengungkap Rahasia-Rahasia Mencengangkan Ormas Keagamaan Paling Kontroversial (Jakarta: Nun Publisher, 2008), h. 173.

${ }^{28}$ Habib Muhammad Riziq Shihab, (2008), h. 251. 
pemilik atau peguasa tempat maksiat tersebut, serta Mabes LPI sebagai laporan dan pemberitahuan (dilampirkan surat pertama, kedua, dan ketiga).

Sementara apabila tempat tersebut illegal maka cara yang dilakukannya adalah: 1). Kirimkan surat protes dan peringatan keras ke pemilik atau penguasa tempat maksiat tersebut, dengan tembusan ke Lurah, Camat, Binmas atau Kapolsek, Danramil, dan ulama setempat sebagai pemberitahuan, serta ke Mabes LPI sebagai laporan. 2). Bila tidak ditanggapi dalam waktu sekurang-kurangnya satu minggu dan selambatlambatnya satu bulan, maka libatkan masyarakat setempat untuk mengambil inisiatif lain dalam upaya menutup tempat maksiat tersebut, yang dalam pelaksanaannya wajib koordinasi dengan Mabes LPI dan aparat pemerintah atau keamanan yang berwenang.

Prosedur di atas digunakan oleh FPI untuk menutup sebuah tempat yang mereka anggap maksiat, baik tempat itu legal maupun illegal. Beberapa kasus aksi sweeping yang dilakukan oleh FPI menunjukkan hal demikian. Misalnya penutupan sebuah warung di Kecamatan Gondang yang menjual minuman keras. Pada aksi ini Yus Aliansyah mengatakan bahwa: ${ }^{29}$

"Penjualnya suami istri dan anaknya menjadi pelayan. Dan memiliki preman. Masyarakat tidak berani (menutup warung itu, red). Masyarakat minta tolong ke FPI sampai dijanjikan jika FPI bisa menutup tempat tersebut maka satu kampong ini akan ikut FPI. masyarakat sudah capek manggil siapa saja, bahkan seorang kiai sering diundang ke situ belum juga bisa menutupnya. FPI rombongan satu mobil menghampiri kafe tersebut, satu mobil berisi 7 orang rombongan dari Malang. Sesampai di tempat Unung memasang bendera FPI di depan rumah warga. Ditemukan beberapa krat bir bintang. Pada malam hari pemilik kafe, warga, polisi, FPI, berkumpul di balai desa untuk meminta persetujuan penutupan kafe tersebut. Akhirnya pemilik kafe pun menandatangi untuk menutup kafe tersebut, dan hingga saat ini kafe tersebut tidak pernah buka lagi”.

Sementara contoh penutupan atau aksi sweeping di tempat legal dibuktikan pada kasus penutupan tempat karaoke di Desa Telasih. Menurut pengakuan FPI Mojokerto, mereka sudah mengirimkan surat kepada Kepala Desa, Polsek setempat, Pemda setempat, namun semua pihak tidak menanggapi surat dari FPI. Pada akhirnya, FPI mengatasnamakan masyarakat melakukan aksi sweeping di tempat tersebut. Aksi ini dilakukan selama beberapa kali. Aksi pertama belum berhasil dan tidak terjadi konflik

\footnotetext{
${ }^{29}$ Yus Aliansyah, Petinggi FPI Mojokerto, wawancara, 18 Mei 2017.
} 
fisik. Sementara aksi kedua dan ketiga terjadi aksi kekerasan atau konflik lantaran menurut pengakuan FPI pihak karaoke sudah mempersiapkan preman.

Aksi sweeping lainnya juga dilakukan oleh FPI dengan menyerbu toko-toko atau swalayan yang mereka anggap menjual minuman keras/beralkohol. Di salah satu swalayan di Brangkal, Sooko, salah seorang saksi melihat aksi sweeping FPI di swalayan tersebut dibarengi dengan tindakan kekerasan dengan memecah kaca toko dan merampas barang-barang yang ada di dalam toko. Menurut pengakuan salah seorang anggota FPI, aksi ini dilakukan lantaran mereka menjual minuman keras yang di luar batas ketentuan perundang-undangan. ${ }^{30}$ Namun, meski ada undang-undang yang mengatur peredaran minuman berakohol, FPI tetap berdalih bahwa semua jenis minuman beralkohol, berapapun kadar alkoholnya, tetap haram dan dilarang untuk beredar di masyarakat. Berdasarkan argumentasi ini FPI tidak mentolerir adanya peredaran minuman beralkohol di masyarakat.

Aksi sweeping yang dilakukan oleh FPI Mojokerto masih dilakukan secara bersama-sama. Hal ini disebabkan karena FPI Mojokerto belum terstruktur secara rapi dan belum memiliki badan laskar sendiri. Namun peneliti menemukan hal yang menarik ketika bertanya-tanya tentang massa aksi yang diajak. Menurut pengakuan Yus Aliansyah, ia memobilisasi massa anak-anak muda yang sedang mabuk-mabukan di sebuah kawasan pasar Brangkal, dekat dengan rumah Yus Aliansyah, untuk aksi sweeping atau demonstrasi. Menurut pengakuannya hal ini dilakukan untuk mengalihkan kebiasaan mereka dari yang minum-mimuna ke aksi yang lebih baik lagi. Dari latar belakang tersebut maka tidak heran apabila mereka sampai pada perusakan tempattempat umum dan fasilitas lainnya. Dari pengamatan Ian D. Wilson mengatakan bahwa aksi premanisme tersebut telah ada sejak masa Orde Baru. Mereka kemudian mendapat tempat lagi ketika bergabung dengan ormas seperti FPI, FBR dan ormas lainnya. Wilson

${ }^{30}$ Dalam undang-undang Menteri Perdagangan No. 20/M-DAG/4/2014 Tentang Pengendalian dan Pengawasan Terhadap Pengadaan, Peredaran, dan Penjualan Minuman Beralkohol, disebutkan bahwa terdapat tiga golongan minuman berakohol yang beredar di Indonesia, yaitu Golongan A minuman yang mengandung etil alkohol dengan kadar sampai dengan 5\%, Golongan B minuman yang mengandung etil alkohol dengan kadar lebih dari 5\%-20\%, Golongan C minuman yang mengandung etil alkohol dengan kadar lebih dari 20\% sampai 55\%. Dalam https://peraturan.bpk.go.id/Home/Download/120061/Permendag $\% 20$ No. $\% 2072 \% 20$ Tahun $\% 202014 . p d f$ 
kemudian menyebut preman tersebut dengan istilah centeng masyarakat. ${ }^{31}$ Mereka bisa menjadi polisi dan hakim sekaligus di masyarakat tersebut.

Ketika mereka terlibat dalam aksi FPI, maka sudut pandangnya juga berguna untuk membentengi mereka jeratan hukum. Hukum yang digunakan tidak diakui sehingga mereka bebas untuk bertindak sesuai dengan apa yang diinginkannya. Hal ini juga diperkuat oleh Habib Rizieq yang membolehkan bertindak dengan tangan atau kekerasan sebagai jalan untuk menghilangkan kemaksiatan di masyarakat.

Meskipun gerakan FPI di Mojokerto belum terlalu massif, namun hal itu sudah merepresentasikan tentang apa yang selama ini diperjuangkan yaitu untuk menerapkan syariat Islam. Dua cara di atas, melibatkan diri dengan sistem demokrasi dan aksi sweeping, memerlukan mobilisasi massa untuk merealisasikan syariat Islam. Menurut Habib Rizieq, syariat Islam merupakan hukum Tuhan yang tidak bisa digantikan dengan hukum manusia. Hukum manusia yang diterapkan di Indonesia saat ini penuh dengan kecacatan dan perlu diganti dengan hukum Tuhan. Habib Rizieq kemudian menyebut hukum Indonesia saat ini sebagai hukum jahiliyah. ${ }^{32}$

Menurut Habib Rizieq adanya berbagai kemaksiatan di masyarakat disebabkan karena tidak diterapkannya syariat Islam sebagai payung hukum negara. Bahkan pemerintah dinilai melindungi kepentingan bisnis dibalik merebaknya kemaksiatan di masyarakat. Demokrasi yang digunakan oleh Indonesia tidak bisa menyelesaikan persoalan kemaksiatan. Menurut Habib Rizieq, demokrasi tak ubahnya seperti babi. Demokrasi bisa mendatangkan berbagai macam keburukan dalam masyarakat, misalnya presiden dipilih atas suara terbanyak. Suara seorang ulama dengan pelacur dianggap sama, melalui demokrasi negara membiarkan kelompok-kelompk sesat bermunculan, melalui demokrasi sistem ekonomi dikuasai oleh antek asing. ${ }^{33}$

Keterlibatan anggota FPI Mojokerto dalam pemilu bukanlah suatu sikap penerimaan FPI atas demokrasi, FPI justru memanfaatkan demokrasi sebagai jalan untuk menerapkan sistem syariat Islam. Apabila partai Islam yang dipilih menjadi orang nomor satu di kabupaten atau kota, maka langkah selanjutnya adalah melakukan koordinasi dengan pemimpin terpilih untuk bernegosiasi demi terwujudnya sistem

\footnotetext{
${ }^{31}$ Ian D. Wilson, (2018), Loc.Cit.

${ }^{32}$ Al-Habib Muhammad Rizieq bin Husein Syihab, (2012), h. 181.

${ }^{33}$ Al-Habib Muhammad Rizieq bin Husein Syihab, Wawasan Kebangsaan Menuju NKRI Bersyariat, Cet. 1 (Jakarta: Suara Islam Press, 2012), h. 109-12.
} 
pemerintahan yang berlandaskan syariat Islam. Hal serupa juga disampaikan oleh Yus Aliansyah yang mengatakan bahwa koordinasi dengan pemerintah kota adalah cara yang tepat untuk memperkenalkan konsep syariat Islam. Langkah ini merupakan upaya baru yang dilakukan oleh FPI pasca Munas di Bogor 2012. Sebelum itu, upaya penerapan syariat dilakukan dengan cara aksi demonstrasi dengan mengusung tema penerapan Piagam Jakarta sebagai ideologi negara. Menurut Habib Rizieq, Piagam Jakarta memuat semangat terciptanya penerapan syariat Islam di Indonesia. ${ }^{34}$

Di sisi lain, keterlibatan anggota FPI dalam pemilu di Indonesia menunjukkan inkonsisteni gerakan. Pasalnya Habib Rizieq, selaku Imam Besar FPI, berkata bahwa demokrasi adalah sistem kafir yang tidak bisa digunakan di Indonesia. Namun Habib Rizieq justru mendorong anggotanya terlibat dalam pemilu untuk memilih, mendukung dan membantu calon pemimpin yang menurut FPI ideal. Hal ini berbeda dengan Partai Keadilan Sejahtera (PKS) yang sejak awal telah melibatkan dirinya dalam perpolitikan Indonesia untuk mewujudkan sebuah sistem pemerintahan Islam. PKS tidak menolak untuk mendirikan sebuah partai. Bagi PKS, melibatkan diri dalam demokrasi merupakan salah satu cara yang bisa dilakukan untuk menerapkan syariat Islam dalam skala nasional. ${ }^{35}$

Perlu diketahui bahwa Habib Rizieq dan PKS memiliki hubungan ideologi. PKS merupakan kepanjangan tangan Ikhwanul Muslimin Mesir dan Sayyid Qutb merupakan sang ideolognya, sementara pemikiran-pemikiran politik Habib Rizieq banyak dipengaruhi oleh Sayyid Qutb. Hal ini bisa dilihat, misalnya, dalam terminologi Habib Rizieq ketika menggunakan konsep jahiliyah dan hakimiyat dalam bangunan pemikirannya untuk menilai keadaan di Indonesia. ${ }^{36}$ Selain itu juga, Habib Rizieq mengambil semangat jihad Sayyid Qutb yang diaplikasikan ke dalam laskar Jihad-nya FPI sebagai sebuah satuan yang bergerak dalam bidang anti-kemaksiatan. Meskipun respon dan sikap terhadap demokrasi di Indonesia tidak sama, namun FPI dan PKS memiliki kesamaan ideologi tentang penerapan syariat Islam.

\footnotetext{
${ }^{34}$ Al-Habib Muhammad Rizieq bin Husein Syihab, Hancurkan Liberalisme, Tegakkan Syariat Islam (Jakarta: Suara Islam Press, 2011), h. 93.

${ }^{35}$ M. Imdadun Rahmat, Ideologi Politik PKS; Dari Masjid Kampus Ke Gedung Parlemen (Yogyakarta: LKiS, 2008).

${ }^{36}$ Al-Habib Muhammad Rizieq bin Husein Syihab, (2012), Loc.Cit.
} 
Perbedaan ini bisa terjadi lantaran Sayyid Qutb sendiri tidak memiliki sebuah konsep bernegara yang baku. Dalam buku Ma'alim fi al-Thariq, Sayyid Qutb berpandangan bahwa manhaj (sistem) selain Islam adalah manhaj jahiliyah. Sistem Islam, dalam istilah lain hakimiyat, dan sistem jahiliyah merupakan terminologi paling orisil dari Sayyid Qutb. Sayyid Qutb mengatakan bahwa sistem Islam itu paling unggul dibanding dengan sistem yang lain atau non Islam. Menurut Sayyid Qutb, apabila sistem negara tidak didasarkan pada aspek Islam maka sistem itu dikatakan jahiliyah. Lebih lanjut Sayyid Qutb mengatakan bahwa "Masyarakat jahiliyah adalah setiap masyarakat yang tidak semata-mata mengikhlaskan penghambaan dirinya kepada Allah saja. Penghambaan diri ini termasuk juga dalam bentuk konsepsi kepercayaan, upacara peribadatan dan perundang-undangan. Dengan definisi ini maka termasuk dalam lingungan masyarakat jahiliyah itu adalah semua masyarakat yang terdapat di atas dunia ini sekarang."37

Konsep jahiliyah merupakan sebuah penggambaran tentang kehidupan sebelum Islam. Istilah ini disematkan untuk menggambarkan sebuah masyarakat yang tidak tahu tentang pengetahuan. Namun istilah ini kemudian dikembangkan oleh Sayyid Qutb untuk menggambarkan kondisi masyarakat kontemporer. Sayyid Qutb mengatakan bahwa istilah jahiliyah tidak hanya merujuk pada komunitas masyarakat pra-Islam, melainkan juga sebagai gambaran tentang kehidupan masyarakat modern saat itu. Maka dari itu menurut Choudori di era kontemporer saat ini konsep jahiliyah diterjemahkan dengan sebuah istilah perlawanan terhadap pemerintah Tuhan. ${ }^{38}$

Konsep hakimiyat merupakan sebuah gambaran tentang pemerintahan yang didasarkan atas syariat Islam. Konsep hakimiyat sendiri, apabila dicermati dengan teliti, tidak merujuk pada salah satu sistem negara saat ini. Sayyid Qutb tidak memiliki sebuah gagasan tentang bentuk negara. Sayyid Qutb hanya berhenti pada masalah pemerintahan Islam bukan pada sistem negara, misalnya negara demokrasi, monarki atau lainnya. ${ }^{39}$ Dari sini bisa dipahami kenapa PKS mau berdamai dengan demokrasi lantaran yang coba diusung adalah demokrasi yang berdasarkan syariat Islam. Namun berbeda dengan

${ }^{37}$ Sayyid Qutb dalam M. Zaki Mubarak \& Iim Halimatusa'diyah, Op.Cit., h. 38.

${ }^{38}$ Khatab, Op.Cit., h. 6.

${ }^{39}$ Antoni Black, Pemikiran Politik Islam Dari Masa Nabi Hingga Kini (Jakarta: Serambi Ilmu, 2001). 
Habib Rizieq yang secara terang-terangan menolak sistem demokrasi karena menurutnya penuh dengan kecacatan sehingga tidak perlu digunakan lagi.

Upaya pernapan syariat Islam di Mojokerto di sisi lain menimbulkan persoalan baru yaitu dualitas hukum yang ada di Mojokerto. FPI menggunakan perspektif syariat Islam sebagai cara pandang atas masyarakat berdampak pada pengalihan sistem hukum yang berlaku. Hukum di Mojokerto sudah diatur dalam undang-undang. Namun aturan ini tidak indahkan oleh FPI dengan mengabaikannya begitu saja. Kasus-kasus sweeping yang dilakukan tidak sedikit yang menuai konflik, lebih-lebih dengan kekerasan. Dalam hal ini, menurut Najib Azca gerakan FPI di Mojokerti bisa dikategorikan ke dalam gerakan radikalisme intoleran ekslusif dikarenakan adanya semacam penarikan diri dari proses hukum yang ada. ${ }^{40}$ FPI terkesan tidak menghiraukan pemerintah selaku pemilik hak dan kewajiban. FPI bertindak hanya dengan mendasarkan pada legitimasi agama yang mereka tafsrikan sendiri. Dengan begitu, segala aturan yang dibuat oleh manusia boleh ditentang karena sifatnya yang temporer.

Pada aksi sweeping yang dilakukan oleh FPI Mojokerto justru memperlihatkan dengan jelas bagaimana hukum di Mojokerto diabaikan begitu saja. Meskipun dalam prosedur yang dimiliki oleh FPI ada semacam laporan pada pemerintah setempat, akan tetapi tindakan teror dengan mengatasnamakan agama yang dilakukan pada warga lokal menyebabkan terjadinya konflik. Alih-alih ingin memberantas kemaksiatan dengan berkedok agama, justru mereka memperlihatkan keganasan dari agama itu sendiri. Negara tidak dihadirkan sebagai penengah, melainkan dianggap sudah gagal dalam melaksanakan roda pemerintahan karena membiarkan adanya toko yang menjual minuman keras. Apalagi ketika melakukan aksi, para aktivis FPI menggunakan simbol dengan berbaju putih-putih. Meskipun atribut demikian sudah menjadi identitas FPI secara umum, akan tetapi hal itu membuat citra FPI semakin esklusif. Simbol semacam itu memperlihatkan corak ideologis yang selama ini dipegang oleh FPI. Publik akan mudah menilai bahwa orang-orang yang berdemonstrasi dan melakukan aksi sweeping adalah aktivis FPI.

Dengan begitu, gerakan sosial keagamaan yang dilakukan oleh FPI Mojokerto dilakukan dengan berbagai cara, sebagaimana yang sudah dijelaskan di atas. 
Keberhasilan dalam melakukan gerakan bisa dilihat dari proses mobilisasi massa. Gerakan FPI Mojokerto tidak akan berhasil jika dilakukan tanpa ada taktik atau cara untuk memobilisasi massa. McCarthy mengungkapkan bahwa struktur mobilisasi adalah sejumlah cara kelompok gerakan sosial melebur dalam aksi kolektif termasuk di dalamnya taktik gerakan dan bentuk gerakan sosial. ${ }^{41}$

\section{Kesimpulan}

Penelitian ini menemukan bahwa penerapan syariat Islam di Mojokerto yang dilakukan oleh FPI melalui berbagai macam cara. FPI memframing sebuah isu sosial, seperti prostitusi, minuman keras, merupakan kebiasaan masyarakat jahiliyah yang harus dilawan. Framing ini menjadi rasionalisasi gerakan FPI untuk memobilisasi massa. Gerakan ini mendapat kesempatan politik ketika ada beberapa agen FPI yang menjalin kerjasama dengan elit politik, sehingga hal itu mempermudah untuk mencapai tujuan. Sementara itu, adanya keterbukaan sistem politik dimanfaatkan oleh FPI untuk terlibat di dalamnya. Secara kolektif FPI memanfaatkan massa dan kesempatan politik dalam demokrasi untuk berunjuk rasa melawan atau menentang tempat prostitusi. FPI juga melibatkan diri dalam sistem demokrasi untuk memilih pemimpin muslim ketika Pemilu dan/atau Pilkada dilakukan. Dengan harapan, pemimpin tersebut bisa diajak untuk bekerjasama dalam merealisasikan penerapan syariat Islam di Mojokerto.

Strategi lainnya dilakukan FPI secara inkonstitusional. Cara ini dilakukan apabila tempat yang diduga menjual minuman keras atau menjadi tempat prostitusi tidak menutupnya meskipun sudah diberi surat pemberitahuan. Ketika surat itu diabaikan dan warung atau tempat itu masih melayani pelanggan, maka FPI akan menggerakkan massanya untuk menutup secara paksa. Strategi ini dapat dilakukan karena mereka menganggap bahwa negara sedang mengalami krisis sehingga ada kesempatan yang bisa dimanfaatkan untuk melakukan cara-cara di luar konstitusi.

\footnotetext{
${ }^{41}$ Abdul Wahib Situmorang, Op.Cit., h. 38.
} 


\section{DAFTAR PUSTAKA}

Azca, Muhammad Najib. "Yang Muda, Yang Radikal: Refleksi Sosiologis Terhadap Fenomena Radikalisme Kaum Muda Muslim Di Indonesia" dalam Maarif Insitute, Vol. 8, No. 1 (2013), h. 14-44.

Benford \& David Snow. "Framing Processes and Social Movements: An Overview and Assessment” dalam Journal Annu. Rev. Social, Vol. 26 (2000), h. 611-39.

Black, Antoni. Pemikiran Politik Islam Dari Masa Nabi Hingga Kini. Jakarta: Serambi Ilmu, 2001.

Buehler, Michael. The Politics of Shari'a Law: Islamist Activists and the State in Democratizing Indonesia. Cambridge University Press, 2016.

Diani, Mario \& Donatella Della Porta. Social Movemente: An Introduction. New York: Blackwell Publishing Ltd, 2006.

Khatab, Sayed. "Hakimiyyah and Jahiliyyah in the Thought of Sayyid Qutb" dalam Middle Eastern Studies, Vol. 38, No. 3 (2002), h. 145-70.

Klandermans, Bert. "Mobilization and Participation: Social-Psychological Expansions of Resource Mobilization Theory" dalam American Sociological Review, Vol. 49, No. 5 (1984), h. 583-600.

McAdam, Doug, et.al. Comparative Perspectives on Social Movements: Political Opportunities, Mobilizing Structures, and Cultural Framings. Cambridge University Press, 1996.

Mubarak, M. Zaki \& Iim Halimatusa'diyah. Politik Syariat Islam Idiologi Dan Pragmatisme. Jakarta: Pustaka LP3ES, 2014.

Ng, Al-Zastrouw. Gerakan Islam Simbolik; Politik Kepentingan FPI. Yogyakarta: LKIS, 2006.

Qutb, Sayyid. Petunjuk Jalan. Jakarta: Media Dakwah, 1994.

Rahmat, M. Imdadun. Ideologi Politik PKS; Dari Masjid Kampus Ke Gedung Parlemen. Yogyakarta: LKiS, 2008.

Rosadi, Andri. Hitam-Putih FPI: Mengungkap Rahasia-Rahasia Mencengangkan Ormas Keagamaan Paling Kontroversial. Jakarta: Nun Publisher, 2008.

Situmorang, Abdul Wahib. Gerakan Sosial: Teori Dan Praktik (Yogyakarta: Pustaka Pelajar, 2013. 
Syihab, Al-Habib Muhammad Rizieq bin Husein. "Pengaruh Pancasila Terhadap Penerapan Syariat Islam di Indonesia". Disertasi. Kuala Lumpur: Jabatan Fiqh dan Usul, Akademi Pengajian Islam, Universiti Malaya, 2012.

_ Hancurkan Liberalisme, Tegakkan Syariat Islam. Jakarta: Suara Islam Press, 2011.

- Wawasan Kebangsaan Menuju NKRI Bersyariat. Jakarta: Suara Islam Press, 2012.

_ Dialog FPI-Amar Ma'rūf Nahī Munkar. Jakarta: Ibnu Saidah, 2008.

Wilson, Ian D. "Resisting Democracy: Front Pembela Islam and Indonesia's 2014 Elections" dalam Ulla Fionna (Ed.), ISEAS Perspective: Watching the Indonesian Elections 2014. Singapore: ISEAS-Yusof Ishak Institute, 2015.

. Politik Jatah Preman: Ormas dan Kuasa Jalanan di Indonesia Pasca-Orde Baru. Jakarta: Marjin Kiri, 2018.

\section{Internet}

Liputan6.com. "Video: FPI Bentrok dengan Pekerja Lokalisasi Balongcangkring" dalam https://www.liputan6.com/news/read/ 2454450/video-fpi-bentrok-denganpekerja-lokalisasi-balongcangkring diakses 10 Mei 2020.

Inilahmojokerto.com. "Mojokerto belum Bebas Prostitusi" dalam https://inilahmojo kerto.com/07/12/2016/ mojokerto-belum-bebas-prostitusi/ diakses 08 Mei 2020.

Bhirawa, Danu. "Kota Mojokerto Targetkan 29 Mei Bebas Prostitusi" dalam https://www.harianbhirawa.co.id/kota-mojokerto-targetkan-29-mei-bebasprostitusi/ diakses 8 Mei 2020.

Wongkaren, Zora A. "Agama dan Fanatisme Berlebihan" dalam https://gagasanhukum. wordpress.com/tag/zora-a-wongkaren/ diakses 10 Mei 2020.

\section{Wawancara}

Rafiq, Anggota FPI Mojokerto, wawancara, 17 Mei 2017.

Unung, Anggota FPI Mojokerto, wawancara, 20 Mei 2017.

Yus Aliansyah, Petinggi FPI Mojokerto, wawancara, 18 Mei 2017. 